\title{
Study on Urban Residents’ Willingness to Buy the Products of Rural Tourism*
}

\author{
Haibo Zhu, Ruihu Wu
}

Business School, Center South of Forest and Technology University, Changsha, China.

Email: qnlkw@126.com

Received April 19 ${ }^{\text {th }}, 2012$; revised May $4^{\text {th }}, 2012$; accepted May 20 $0^{\text {th }}, 2012$

\begin{abstract}
The level of value injected into the rural economy is dependent consumers acceptance of rural tourism. Data was obtained through primary research conducted in the three provinces in China of Hunan, Guangdong and Gansu, the paper explores urban residents' attitude to rural tourism and then estimates their willingness to pay for rural tourism products, utilizing hypothesis-evaluation to find a valid conclusion. The results show that their willingness is affected by gender, educational background, level of income; personal travel frequency, tourism form, aggregate demand form rural tourism, acceptance for rural tourism and the price of tourism in other cities have significant effect on their willingness to pay. The WTP proves that urban residents are usually willing to pay 35.1\% more for non-rural tourism than they are for rural tourism.
\end{abstract}

Keywords: Rural Tourism; Purchase Intention; Empirical Analysis; Urban Residents

\section{Introduction}

As a major tourism form, rural tourism has developed so rapidly that it has become a major engine of domestic tourism and a catalyst to economic development and further reform. However, there are some problems associated with this economic development. Sustainability is a key concern. Ultimately it will be the urban resident's type of demand that will shape the future of rural tourism.

The research of rural tourism began in 1958; when Agar explored the benefits tourism in mountain areas brought to local peasants. This kind of researches developed significantly in the 1960s and 1970s, but most of the focus was on farm tourism [1]. It continued through into the beginning of 21th century. From 1980s to 1990s, some scholars' research direction turned into the marketing meaning of rural tourism and its effects on local economy and society. The research field was extended and it is in this stage that human being became one of focuses of the research. Keogh (1990) and Hernanadezetal (1996) thought that it was necessary to design a questionnaire and survey the local residents attitude towards tourism development, before facilities were built [2]. Peter Mason (2000) chose New Zealand because the case made a conclusion based on a national survey about how community residents' attitudes toward developing

*The empirical analysis is derived from urban residents living in Hunan, Guangdong and Gansu Province in China. tourism was with apparent sex difference [3].

At the beginning of this century, rural tourism became a main research topic in the area of tourism with the development of rural tourism scholars that is significantly important for rural tourism [4], which emphasized the research on their behaviour of motive and manner. Lourdes Molera had got the view of market choice after investigating rural tourist to the southeast of Spain. Martin Oppermann (1996) explored the effect of German tourist's characteristic on rural tourism. Rosa M. Hernandez Maestro explained tourist's attitude toward rural tourism and the process of their emotional change between perceived service quality and satisfaction [5].

In China, The present research on the relationship between tourist and the product of rural tourism is at the beginning of stage. Taking French enterprise Le Relais de Chenillé for example, Fang Zhongquan and Guo Yixian summarized the marketing and its experiences of rural tourism in France [6]. Zhang Jianguo and Yu Yiwu firstly made a research on the trend of urban resident's demands for the product of rural tourism and found that urban resident's consumption motives involve demands in their body and mind, for example the demands for returning to the nature, learning demand, nostalgic demand and multiple demand [7]. However, there is nearly no research on the purchase intention of rural tourism products from the present literature, it is only mentioned a little in the literature on rural tourism products. So ana- 
lyzing the purchase intention to rural tourism products from the standpoint of urban residents from this research is able to fill in the gap of the field about the relationship between rural tourism products and tourist's purchase intention, and provide constructive advice to the development of rural tourism in China.

\section{Investigation and Statistics}

\subsection{Investigation Method}

In May and July in 2008, February and August in 2009, the author conducted masters and undergraduates to randomly send out 400 questionnaires to tourists at some pastoral restaurants and farms nearby Changsha city, 100 questionnaires at universities, organizations and enterprises, in all 500 questionnaires. They mostly are filled in on the spot and totally 500 questionnaires have been retrieved, among which there are 477 available questionnaires and with a ratio of $95.4 \%$.

\subsection{The Result of Investigation}

- Respondents' basic statistical characteristics. As shown in Table 1.

- The analysis of tourist's recognition of rural tourism products. The investigation has showed that tourists are familiar with rural tourism and there $89.1 \%$ of tourists are with some recognition of rural tourism products (Table 2).

- The analysis of tourist's recognition of rural tourism benefits. $42.8 \%$ of tourists think that rural tourism is good for relaxation in both mentally and physically, they can relieve working-pressure and breathe the fresh air by the countryside travel. $40.7 \%$ take rural tourism as a right way to gather and communicate with friends; $25.2 \%$ want to broaden their horizon by doing farm work and recognizing farm products in rural tourism; and $48.4 \%$ believe that rural tourism contributes cultivating hardship endurance which is helpful for child's education (Table 3).

- Tourists' attitude toward developing rural tourism. In survey, it is also clear that most of tourists are admissible for rural tourism. Tourists who are consent and completely consent are $81.1 \%$, while there are only $5.9 \%$ who expressed dissent about it (Table 4).

- Tourist's recognition on rural tourism development. According to Richter scale ("great, comparatively great, normal, a little, little”), tourist's recognition of rural tourism on enhancing local economy development can be concluded as Table 5 .

\section{The Estimation of Tourist's Purchase Intention}

\subsection{Regression Analysis}

In regression analysis, Classification dependent variable
Table 1. Respondents' demographic characteristics.

\begin{tabular}{|c|c|c|c|}
\hline Characteristics & Description & Person Number & Ratio \\
\hline \multirow[t]{2}{*}{ Gender } & male & 248 & 52 \\
\hline & female & 229 & 48 \\
\hline \multirow[t]{5}{*}{ Age } & $<22$ & 10 & 2.1 \\
\hline & $22-35$ & 238 & 49.9 \\
\hline & $36-45$ & 143 & 30.0 \\
\hline & $46-55$ & 70 & \\
\hline & 56 or more & 16 & \\
\hline \multirow[t]{3}{*}{ Residence } & city & 411 & 86.2 \\
\hline & suburban & 52 & 10.9 \\
\hline & country & 14 & 2.9 \\
\hline \multirow[t]{3}{*}{ Birth family } & country & 28 & \\
\hline & suburban & 82 & \\
\hline & city & 367 & \\
\hline \multirow{4}{*}{$\begin{array}{l}\text { Family } \\
\text { constructure }\end{array}$} & single & 237 & 49.7 \\
\hline & couple & 42 & 8.8 \\
\hline & three & 155 & 32.5 \\
\hline & more than three & 43 & 9.0 \\
\hline \multirow{4}{*}{$\begin{array}{c}\text { Educational } \\
\text { attainment }\end{array}$} & $\begin{array}{l}\text { technical/high school or } \\
\text { lower }\end{array}$ & 79 & 16.6 \\
\hline & Junior college & 171 & 35.8 \\
\hline & regular college & 155 & 32.5 \\
\hline & Master or higher & 72 & 15.5 \\
\hline \multirow{5}{*}{$\begin{array}{l}\text { Monthly } \\
\text { income }\end{array}$} & $¥ 1000$ or less & 121 & 25.4 \\
\hline & $¥ 1001$ - ¥2000 & 129 & 27.0 \\
\hline & $¥ 2001$ - ¥3000 & 84 & 17.6 \\
\hline & $¥ 3001$ - ¥4000 & 76 & 16.0 \\
\hline & $¥ 4000$ or more & 67 & 14.0 \\
\hline \multirow{6}{*}{$\begin{array}{l}\text { Rural tourism } \\
\text { frequency }\end{array}$} & Once a week or more & 45 & 9.4 \\
\hline & Once a month or more & 78 & 15.5 \\
\hline & Once two months & 148 & 31.1 \\
\hline & Once three months & 110 & \\
\hline & Once six moths & 65 & \\
\hline & Once a year or less & 35 & \\
\hline \multirow{3}{*}{$\begin{array}{l}\text { Annual tourism } \\
\text { consumption }\end{array}$} & $¥ 501$ - ¥1000 & 72 & 16.9 \\
\hline & $¥ 1001$ - ¥3000 & 77 & 18.1 \\
\hline & More than $¥ 3000$ & 126 & 29.6 \\
\hline \multirow{2}{*}{$\begin{array}{l}\text { Rural tourism } \\
\text { purchase form }\end{array}$} & Travel agent & 108 & \\
\hline & By self & 369 & \\
\hline
\end{tabular}

Table 2. Tourist's recognition of rural tourism products.

\begin{tabular}{ccc}
\hline & Person number & Ratio \\
\hline Unfamiliar & 52 & 10.9 \\
Familiar & 194 & 40.7 \\
Very familiar & 231 & 48.4 \\
\hline
\end{tabular}


Table 3. Rural tourism benefits.

\begin{tabular}{lcc}
\hline \multicolumn{1}{c}{ Benefits } & $\begin{array}{c}\text { Person } \\
\text { number }\end{array}$ & Ratio \\
\hline Gather and communicate with friends & 194 & 40.7 \\
Relieve mental stress and breathe the fresh air & 204 & 42.8 \\
Broaden their horizon & 120 & 25.2 \\
Helpful for child's education & 231 & 48.4 \\
\hline
\end{tabular}

Table 4. Tourists' attitude toward developing rural tourism.

\begin{tabular}{lcc}
\hline \multicolumn{1}{c}{ Tourists' attitude } & Person number & Ratio \\
\hline Completely sympathy & 145 & 30.4 \\
Sympathy & 242 & 50.7 \\
No interest & 37 & 7.8 \\
Little sympathy & 25 & 5.2 \\
Dissent & 28 & 5.9 \\
\hline
\end{tabular}

Table 5. Tourist's recognition of enhancing effect of rural tourism on local society or economy.

\begin{tabular}{lcc}
\hline Tourist's recognition & Person number & Ratio \\
\hline Great & 85 & 17.8 \\
Comparatively great & 162 & 34.0 \\
Normal & 147 & 30.8 \\
A little & 71 & 14.9 \\
Little & 22 & 4.6 \\
\hline
\end{tabular}

is analysed with logit, namely Consumer's rural tourism product purchase is looked as the result of synergism of price, accessibility and respondent's characteristic, illustrated with a function: $V=F$ (price, accessibility, income, gender, age, the recognition of rural tourism product, purchase frequency), namely as:

$$
V_{i n}=\beta_{i 0}+\beta_{1} P_{i n}+\beta_{i 2} X_{n 2}+\wedge+\beta_{i k} X_{n k}+\varepsilon_{i n}
$$

In the function, $V_{i n}$ is the utility when the $n$th respondent chooses $i$ th rural tourism product; $P_{i n}$ is the price of product $i ; \quad X_{n 1}, \cdots, X_{n k}$ is respondent $n$ 's characteristic; The error item $\varepsilon_{i n}$ is supposed to be independent and consistent; Parameters (except $\beta_{1}$ ) in the function are all seemed as zero; The probability when the $n$th consumer purchases product $i$ is:

$$
P_{n}=\frac{1}{1+\exp \left(-\beta_{\text {in }} X_{\text {in }}\right)}=\frac{\exp \left(\sum \beta_{\text {in }} X_{\text {in }}\right)}{1+\exp \left(\beta_{\text {in }} X_{\text {in }}\right)}=\frac{\exp \left(V_{\text {in }}\right)}{\sum_{j} \exp \left(V_{\text {in }}\right)}
$$

For logistic regression, the linear combination of independent variable need to be put at a side of the equation, which can turn to be a linear form of independent variable. Then through log conversion the linear equation of both probability function and independent variable can be:

$$
\ln \left[\frac{P_{n}}{1-P_{n}}\right]=\sum\left(\beta_{i n} X_{i n}\right)
$$

The purpose of this research is to estimate tourist's purchase intention to rural tourism products. The binary choice probability in purchasing certificated and noncertificated rural tourism products lies on both price and consumer characteristic, whose relation follows logistic function. Logit regression is conducted with SPSS17.0, and $i=0,1$ respectively represented certificated and noncertificated rural tourism products.

Apparently, In accordance with the principle of equal marginal utilities. So consumer's purchase intention to certificated rural tourism products can be represented as:

$$
\begin{aligned}
\beta_{1} P_{0 n}+\varepsilon_{0 n}= & \beta_{10}+\beta_{1}\left(P_{1 n}+W T P_{1 n}\right)+\beta_{12} X_{n 2}+\wedge \\
& +\beta_{1 k} X_{n k}+\varepsilon_{1 n}
\end{aligned}
$$

Suppose the expectation value of error item:

$E\left(\varepsilon_{0 n}\right)=E\left(\varepsilon_{1 n}\right)=0$, then consumer's average purchase intention to each product is:

$$
\overline{W T P}=-\frac{1}{\beta_{1}}\left(\beta_{10}+\beta_{12} \overline{X_{2}}+\wedge+\beta_{1 k} \overline{X_{k}}\right)
$$

\subsection{Hypothesis-Evaluation Method}

This research employ the hypothesis-evaluation method, which after being asked some question the tourist is required to make a choice between two products and the choice change with different price could be observed in this situation.

The drawback of this method (including other method to explain consumer purchase intention) has some difference between consumer's actual choice and the choice in answering questionnaire. After all, respondents need not to pay real money and there is no stimulus to inspire showing their real preference. With the lack of product appropriate to do empirical confirmation it is no better than to use hypothesis-evaluation method. The choice experiment consists of two steps. Step 1, inquire respondents how to make a choice between rural tourism products and other tourism products without any indication. Step 2, each respondent face the same choice, but drive down the price of the product which is not chosen by most respondents. The result shows that the fall in price will attract consumer choosing other tourism products(as urban tourism and sightseeing): with the fall of $5 \%$ price, consumers who turn to choose urban tourism are $10.02 \%$; with the fall of $10 \%$, the consumers are $8.64 \%$; with the fall of $15 \%$, the consumers are $7.96 \%$; with the fall of $20 \%$, the consumers are $26.47 \%$; with the fall of $25 \%$, the consumers are $16.32 \%$; with the fall of $30 \%$, the 
consumers are $9.48 \%$; with the fall of $35 \%$, the consumers are $3.28 \%$; with the fall of more than $40 \%$, the consumers are $27.83 \%$.

\subsection{Regression Result}

The paper estimates the purchase intention to rural tourism with binary logit regression. In the regression model each choice is introduced as a group of observation into regression equation. If a respondent sees no difference between rural tourism products and other ones then his or her choice should be considered as two groups of observation; if a respondent have already made a clear choice his or her choice should be looked as a group of observation. A consumer's choice of rural tourism products is set to be basic status which is represented with 0 ; his or her choice of urban tourism products is represented with 1 ; explanatory variables consist of the price of rural tourism products, respondents' typical demographic characteristic (as age, gender, education, income and region), the degree of urban residents' recognition of rural tourism products and tourism frequency. Table 5 shows the definition of variables and the mean of sample. The regression analysis in research tries to explore how much urban residents would like to pay for avoiding purchasing rural tourism products or how much the price of rural tourism products falls that can attract urban residents to purchase them. Through forward conditional step-wise regression the regression result (Table 6) is got in Step 8, it can be seen in Table 6 that the coefficients of such variables as gender, education, monthly income, purchase frequency, purchase way, the payout in last year, the accessibility and the price of rural tourism products are significantly not 0 at $5 \%$ significant level, and the significance of other variables is not great. The coefficient of variable gender is significantly positive, which shows that the proportion between the female and the male is nearly not great, but the male think higher of social interaction and the female think higher of family relation and child's education.

The coefficient of education is significantly negative which shows that urban residents think higher of purchasing rural tourism products as the increasing education and that consumers with higher education emphasize more tourism quality, environmental protection and environmental education. The negative coefficient of income shows that with increasing income consumers may pay more attention to life quality, leisure and participation in tourism, but not price, which results in the low elastic of price. The positive coefficient of purchase frequency shows consumers with higher purchase frequency
Table 6. Parameter estimate of regressive model.

\begin{tabular}{lcccccc}
\hline & $\beta$ & S.E & Wald & df. & Sig. & $\operatorname{Exp}(\beta)$ \\
\hline GENDER & $0.475^{* *}$ & 0.089 & 28.349 & 1 & 0.000 & 1.607 \\
EDUCA & $-0.685^{* *}$ & 0.050 & 186.455 & 1 & 0.000 & 0.504 \\
INCOME & $-0.214^{* *}$ & 0.051 & 17.836 & 1 & 0.000 & 0.807 \\
FREQU & $0.127^{* *}$ & 0.049 & 6.553 & 1 & 0.010 & 1.135 \\
TRAWAY & & & 9.021 & 2 & 0.011 & \\
TRAWAY(1) & $-0.338^{* *}$ & 0.129 & 6.833 & 1 & 0.009 & 0.713 \\
TRAWAY(2) & -0.045 & 0.111 & 0.161 & 1 & 0.688 & 0.956 \\
EXPENSE & $0.266^{* *}$ & 0.050 & 28.246 & 1 & 0.000 & 1.304 \\
GREE & $0.253^{* *}$ & 0.051 & 24.786 & 1 & 0.000 & 1.288 \\
PRICE & $-3.205^{*}$ & 0.330 & 94.229 & 1 & 0.034 & 0.04 \\
CONSTANT & $-0.304^{*}$ & 0.124 & 6.010 & 1 & 0.014 & 0.738 \\
\hline
\end{tabular}

${ }_{\mathrm{p}}^{*}<0.001,{ }^{* *} \mathrm{p}<0.01, \mathrm{p}$ values are unilateral.

more probably choose rural tourism products, because urban residents with higher purchase frequency will be afraid of the increase of expenditure on tourism for consumption may lead to the accidental choice of rural tourism products. The positive coefficient of the purchase way of tourism agent means that rural tourism products purchased through tourism agent is fewer and most are supplementary not chief tourism destination. The negative coefficient of annual expense of rural tourism means that consumers with higher expense in last year more probably choose urban tourism. The positive coefficient of accessibility means that the increase demand of rural tourism products belongs to inelastic demand, namely the choice of rural tourism products is affected little by tourism expense. The negative coefficient of price means that the higher of the price of rural tourism products, the lower urban residents' purchase intention to rural tourism products and that urban residents are not sensitive to the price in purchasing rural tourism products.

\section{The Estimation of Purchase Intention Ations}

With means and regression coefficients of all available urban residents' purchase intention can be gotten according to Equation (5) and then deduce the purchase intention to rural tourism. The meaning of urban residents' purchase intention to rural tourism products is that urban residents will purchase rural tourism products only at how much lower price of rural tourism products than the price of urban tourism. Purchase intention to rural tourism is defined as the amount of money which urban residents intend to pay for rural tourism. According Equation (5) it is:

$$
\begin{aligned}
\overline{W T P} & =-\frac{1}{\beta_{1}}\left(\beta_{10}+\beta_{12} \overline{X_{2}}+\wedge+\beta_{1 k} \overline{X_{k}}\right)=-\frac{1}{-3.205} \\
\times & {[-0.304+0.475 \times 0.52+(-0.685 \times 2.51)+(-0.214) \times 2.32+0.127 \times 2.99+0.338 \times 0.27+0.266 \times 2.48+0.253 \times 1.93] } \\
& =-26 \%
\end{aligned}
$$


In the model, the price of rural tourism products is standardized as 1 , so all of respondents' average purchase intentions are $-26 \%$, which suggests that usually urban residents will intend to purchase rural tourism products only only at $26 \%$ lower price than that of urban tourism. If on the base of rural tourism products, urban residents would like to pay $35.1 \%(0.26 /(1-0.26)=$ $35.1 \%)$ more for urban tourism.

\section{Conclusion}

The result of research with hypothesis-evaluation on tourists' purchase intention to rural tourism in Changsha city Hunan province shows that the difference of purchase intention among tourists with different characteristic is great. This paper trys to apply some econometrics methods to analysis major factors which affect respondents' purchase intention to rural tourism. The result also suggests that urban residents' purchase intention to rural tourism is significantly affected by gender, education, monthly income, purchase frequency, purchase way, annual expense in rural tourism, the accessibility of rural tourism, the price of rural tourism products. Additionally, the tourists who are male, high educated, high-income, with the purchase way of tourism agent and high accessibility of rural tourism more probably choose to purchase rural tourism products, but the tourists with high purchase frequency and annual expense in tourism more probably choose to purchase urban tourism products.

\section{Author in Brief}

ZHU Haibo (1971 ), male, Associate Professor, received the Master's degree from Center South of Forest and Technology University and now studying for a doctorate in Central South University. Mainly engaged in marketing channel management research work.

\section{Acknowledgements}

This article is supported by the Youth Project funding of Education Department of Hunan Province (project numbers: 09b115), allow us to thank them for the kindness.

\section{REFERENCES}

[1] Z. G. Yao, Q. Su, et al., "Research Perspective of Abroad Rural Tourism,” Economic Geography, Vol. 27, No. 6, 2007, pp. 1046-1049.

[2] S. A. Hernandez, J. Cohen and H. L. Garcia, "Residents' Attitudes towards an Instant Resort Enclave,” Annals of Tourism Research, Vol. 23, No .4, 1996, pp. 755-779.

[3] P. Mason and J. Cheyne, "Residents' Attitudes to Proposed Tourism Development," Annals of Tourism Research, Vol. 27, No. 2, 2000, pp. 391-411. doi:10.1016/S0160-7383(99)00084-5

[4] Q. L. Wu and S. W. Zhen, “Abroad Rural Tourism Research and Its Apocalypse for China-Based on Status Cerebration of the Development of Chinese Rural Tourism,” China Price, 2007, pp. 58-61.

[5] M. Rosa, A. Pablo and S. Libia, "The Moderating Role of Amiliarity in Rural Tourismin Spain,” Tourism Management, Vol. 28, No. 4, 2006, pp. 951-954.

[6] Z. Q. Fang and Y. X. Guo, "The Marketing and Experience of French Rural Tourism Products-The Case of Le Relais de Chenillé,” Cultural Geography, Vol. 97, No. 5, 2007, pp. 76-80.

[7] J. G. Zhang, Y. W. Yu, et al., "The Trend of Urban Residents' Demand for Rural Tourism Products-The Case of Ningbo Residens,” Business Research, Vol. 21, No. 362, 2007, pp. 195-198. 